\title{
The Impact of Principal Leadership Style and Work Discipline on Elementary School Teachers' Performance
}

\author{
Kalimah $^{1 *}$, Edy Harapan ${ }^{2}$, Tahrun $^{2}$
}

\author{
${ }^{1}$ SDN 2 Makarti Jaya \\ ${ }^{2}$ Universitas PGRI Palembang \\ *Corresponding author. Email: Kalimahmujiyono@gmail.com
}

\begin{abstract}
Education is believed to have a very central role in the development process of a nation. Therefore, the role of the principal in leading a school is very influential. This study aims to determine how much influence the principal's leadership style, the effect of work discipline on the performance of Elementry school Makarti Jaya District teachers and the influence of the principal's leadership style and work discipline together on the performance of Elementry school teachers in Makarti Jaya District. The method used in this research is quantitative research methods. This research conducted at Elementry school Makarti Jaya District from October to November 2020. The results showed that the school leadership style had an influence on teacher performance based on the results of the $t$ test analysis. This shows that there is an influence of the principal's leadership style and work discipline there is an influence on teacher performance based on the results of the t test analysis. This shows that there is an effect of work discipline on teacher performance and principal leadership style and work discipline have a joint influence on teacher performance based on the results of the $\mathrm{F}$ test analysis. This shows that there is an influence of the principal's leadership style and work discipline jointly on the performance of teachers in Elementry school Makarti Jayatelah sub-district answered the third hypothesis.
\end{abstract}

Keywords: Education, Leadership Style, School Principal, Elementry School Makarti Jaya

\section{INTRODUCTION}

Education is thought to play a crucial role in a country's growth process. National education serves to improve skills and form the character and culture of a nation with integrity in the sense of educating the nation's life. According to Law Number 20, Article 3 of 2003 concerning the National Education System [1]. However, meeting these demands will not be easy; there are numerous factors that have always been a barrier, such as poverty, underdevelopment, and even cultural chaos.

Leadership has grown over time, as has scientific management, which was invented by scientist Frederick W. Taylor in the early twentieth century and later transformed into a leadership scientist. Leadership is no longer dependent on innate skill or experience, but on careful preparation and training of potential leaders [3]. This is achieved by preparation, investigation, experimentation/experimentation, study, monitoring, and systematic training to improve superior leadership traits so that they can succeed in their tasks.
The principal is a determining figure in the development of education at the school level [3]. From the line of bureaucracy related to the work of education, the principal has the role of implementing all education programs planned by the Central Government down to the operational level in schools. By not underestimating the role of educators and other educational staff, the progress and decline of education is largely determined by the leadership pattern of the principal in implementing the educational vision to be achieved by the school.

A leader style is someone who can influence others and who has managerial authority [4]. Meanwhile, leadership is what leaders do, namely the process of leading a group and influencing the group to achieve a goal. In addition, there are also several definitions of leadership style according to experts. Leadership style is the process of influencing organized group activities to achieve goals [5]. Leadership style is a way of articulating a vision, realizing values, and creating an environment to achieve [6]. Leadership style is the behavior of an individual when he or she directs group activities towards a common goal. 
Head of school comes from two words, namely "Head" and "School". The word head can be interpreted as chairman or leader in an organization or institution. Meanwhile, the word school is defined as an institution where it is a place to receive and give lessons. In short, the principal can be interpreted as the leader of a school or an institution where a place to receive and give lessons.

Some previous studies have contributed to the idea about correlation among principal leadership style, work discipline, and work performance. leadership management of school principals in fostering teacher professionalism can be seen from the side of planning, organizing, implementing, evaluating and following up; potential obstacles faced by school principals can be in the form of lack of information, relying on only certain teachers, financial limitations and lack of knowledge in fostering teacher professionalism; the solution to the obstacles faced is to carry out coaching, supervise, give assignments and carry out self-development activities [7].

Some studies reported that the principal's leadership style has an impact on teacher performance [8], [9]; school organizational culture has an impact on teacher performance[8], [10]; and the principal's leadership style and school organizational culture have an impact on teacher performance [8]; there is a significant influence between work motivation on teacher performance [10]; There is an effect of teacher competence on the quality of learning [11].

From the background, the problem can be formulated is: is there an influence of the principal's leadership style on the performance of the SD Negeri Makarti Jaya District teachers? The purpose of this study was to determine how much influence the principal's leadership style has on the performance of the SD Negeri Makarti Jaya District teachers.

\section{METHODS}

This research was conducted at SD Negeri Makarti Jaya District from October to November 2020. The method used in this research is quantitative research methods. The quantitative research method is to see the effect partially between the existing variables [12], while variables are the object of research, or what is the point of attention of a study [13].

The variables in quantitative research here consist of: Principal Leadership Style (X1) on Teacher Performance (Y), Work Discipline (X2) on Teacher Performance, while testing the hypothesis together, namely Principal Leadership Style (X1) and Work Discipline (X2) on Teacher Performance (Y). Then to test the hypotheses that have been formulated, all the data obtained will be processed and processed with quantitative analysis. It explains that data collection techniques in research can be done using a questionnaire, interview, observation or observation, exams or tests, documentation and so on [13]. In this study, the data collection techniques used by researchers were questionnaires and documentation.

\section{RESULTS AND DISCUSSION}

The Research on the leadership style of school principals and work discipline on teacher performance was carried out in SD Negeri Makarti Jaya District with a population of 262 with a sample size of 173 educators and teaching staff. The data collection tools in this study used a questionnaire that had previously been tested for validity and reliability. The data description that will be presented from the results of this study is to provide a general description of the distribution of data obtained from the field (research location). The data presented is in the form of raw data which is processed using descriptive statistical techniques.

The variable of principal leadership style in this study consisted of 4 (four) indicator dimensions, namely instructive style, consultation style, participation style and delegation style. To test the descriptive analysis of the data on the principal's leadership style variable, it can be done by using the SPSS version 22 program. The results of the descriptive analysis of the data using the SPSS version 22 program on the principal's leadership style variable are as follows:

Based on the results of the calculation of the $\mathrm{F}$ test above, it can be interpreted that if the principal's leadership style and work discipline have a zerosignificance value, the performance of the SD Negeri Makarti Jaya District teacher has a regression value of 2686.209. The principal's leadership style and work discipline have a positive influence on the performance of the SD Negeri Makarti Jaya District teachers of 869,981 . This means that the significance value is 0.000 . Because the significant value (probability) is smaller than $0.05, \mathrm{H} 0$ is rejected. This means that $\mathrm{Ha}$ is accepted thus there is an influence of the principal's leadership style (X1) and work discipline (X2) together on teacher performance $(\mathrm{Y})$ which is equal to 0,000 $<0.05$ and the value of Fcount26,804> Ftable 3.05, so it can be concluded that Hal is accepted, which means there is an influence between organizational culture (X1) and principal leadership (X2) together on teacher performance $(\mathrm{Y})$.

Based on the value above, it is known that the significance value for the effect of $\mathrm{X} 1$ and $\mathrm{X} 2$ simultaneously or together on $\mathrm{Y}$ is equal to 0.000 $<0.005$ and the value of Fcount26,804> Ftable is 3.05, so it can be concluded that $\mathrm{Ha} 3$ is accepted, which means that there is a significant effect of $\mathrm{X} 1$ and $\mathrm{X} 2$ simultaneously against $\mathrm{Y}$. 


\section{CONCLUSION}

The results of descriptive analysis on each variable indicate that the principal's leadership style (X1), it can be seen that the results of the descriptive analysis show that the Principal Leadership Style variable is included in the sufficient category. Work Discipline Variable (X2) the results of the descriptive analysis indicate it is in the sufficient category. Then the Teacher Performance Variable (Y) results of the descriptive analysis showed it was in the sufficient category. Based on the results of the research that has been done, it can be concluded that school leadership style has an influence on teacher performance based on the results of the $t$ test analysis. This shows that there is an influence of the principal's leadership style on teacher performance in SD Negeri Makarti Jaya District.

\section{REFERENCES}

[1] Undang-Undang Nomor 20 Pasal 3 Tahun 2003 Tentang Sistem Pendidikan Nasional.

[2] Harapan. (2017). Visi Kepala Sekolah Sebagai Penggerak Mutu Pendidikan.

[3] Fahmi. (2018). Mengelolah Manajemen: Teori dan Aplikasi. Bandung: Alfabeta.

[4] Mulyasa. (2013). Manajemen Kepemimpinan Kepala Sekolah. Jakarta: Bumi Aksara.

[5] Sawiyah. (2016). Kepemimpinan Kepala Sekolah. Yogyakarta: Media Fahmi Akademi.

[6] Yukl. 2010. Leadership in Organization, Seventh Edition, Upper Saddle River, New Jersey: Pearson Education Inc.

[7] Rivayanti, Arafat, Y., \& Puspita, Y. (2020). Manajemen Kepemimpinan Kepala Sekolah dalam Pembinaan Profesionalisme Guru . Journal of Innovation in Teaching and Instructional Media, 1(1), 10-17. Retrieved from https://ejournal.karinosseff.org/index.php/jitim/ar ticle/view/25

[8] Royani, I., Fitria, H., \& Rohana. (2020). Pengaruh Kepemimpinan Kepala PAUD dan Kompetensi Guru terhadap Kinerja Guru. Journal of Innovation in Teaching and Instructional Media, 1(1), 36-45. Retrieved from https://ejournal.karinosseff.org/index.php/jitim/ar ticle/view/28

[9] Royani, I., Fitria, H., \& Rohana. (2020). Pengaruh Kepemimpinan Kepala PAUD dan Kompetensi Guru terhadap Kinerja Guru. Journal of Innovation in Teaching and
Instructional Media, 1(1), 36-45. Retrieved from https://ejournal.karinosseff.org/index.php/jitim/ar ticle/view/28

[10] Damayani, T., Arafat, Y., \& Eddy, S. (2020). Pengaruh Kepemimpinan Kepala Sekolah dan Motivasi Kerja terhadap Kinerja . Journal of Innovation in Teaching and Instructional Media, 1(1), 46-57. Retrieved from https://ejournal.karinosseff.org/index.php/jitim/ar $\underline{\text { ticle/view/29 }}$

[11] Comalasari, E., Harapan, E., \& Houtman. (2020). Pengaruh Gaya Kepemimpinan Demokratis Kepala Sekolah, Kompetensi Guru dan Manajemen Kelas Terhadap Mutu Pembelajaran. Journal of Innovation in Teaching and Instructional Media, 1(1), 74-84. Retrieved from

https://ejournal.karinosseff.org/index.php/jitim/ar ticle/view/31

[12] Sugiyono. (2018). Metode Penelitian Kuantitatif. Bandung: Alfabeta

[13] Arikunto, S. (2006). Prosedur Penelitian Suatu Pendekatan Praktik. Jakarta: Rineka Cipta. 